\title{
Functional evidence that the central renin-angiotensin system plays a role in the pressor response induced by central injection of carbachol
}

W.A. Saad, A.C. Luiz, L.A.A. Camargo, J.E.N. Silveira, S. Fóglia, J.V. Menani and William A. Saad
Departamento de Ciências Fisiológicas, Faculdade de Odontologia, Universidade Estadual Paulista, 14801-903 Araraquara, SP, Brasil

\section{Correspondence}

W.A. Saad

Departamento de Ciências

Fisiológicas

Faculdade de Odontologia, UNESP

Rua Humaitá, 1680

14801-903 Araraquara, SP

Brasil

Fax: 55 (016) 222-4823

Presented at the International Symposium "Neuroendocrine Control of Body Fluid Homeostasis", Ribeirão Preto, SP, Brasil,

August 17-20, 1996.

Research supported by FAPESP (Nos. 94/3677-9 and 93/4625-0), CNPq (Nos. 530266/93-8 and 530266/93-9) and FUNDUNESP (No. 350/92-DFP/F/CBS).

Received November 29, 1996 Accepted January 6, 1997

\begin{abstract}
We investigated the effects of losartan, an $\mathrm{AT}_{1}$-receptor blocker, and ramipril, a converting enzyme inhibitor, on the pressor response induced by angiotensin II (ANG II) and carbachol (a cholinergic receptor agonist). Male Holtzman rats (250-300 g) with a stainless steel cannula implanted into the lateral ventricle (LV) were used. The injection of losartan $(50 \mathrm{nmol} / 1 \mu \mathrm{l})$ into the LV blocked the pressor response induced by ANG II ( $12 \mathrm{ng} / 1 \mu \mathrm{l})$ and carbachol $(2 \mathrm{nmol} / 1 \mu \mathrm{l})$. After injection of ANG II and carbachol into the LV, mean arterial pressure (MAP) increased to $31 \pm 1$ and $28 \pm 2 \mathrm{mmHg}$, respectively. Previous injection of losartan abolished the increase in MAP induced by ANG II and carbachol into the LV $(2 \pm 1$ and $5 \pm 2 \mathrm{mmHg}$, respectively). The injection of ramipril $(12 \mathrm{ng} / 1 \mu \mathrm{l})$ prior to carbachol blocked the pressor effect of carbachol to $7 \pm 3 \mathrm{mmHg}$. These results suggest an interaction between central cholinergic pathways and the angiotensinergic system in the regulation of arterial blood pressure.
\end{abstract}

Key words

- Pressor response

- Central angiotensin

- Carbachol

Central injection of the cholinergic agonist carbachol as well as angiotensin II (ANG II) induces pressor responses mediated by sympathetic activation and vasopressin release (1-3). Electrolytic lesions of the anteroventral third ventricle (AV3V) region impair the pressor response to central ANG II or carbachol $(4,5)$. The periventricular $\mathrm{AV} 3 \mathrm{~V}$ region plays an important role in the control of sympathetic activation and vasopressin release (4) and is suggested to be the site of important angiotensinergic synapses involved in fluid, electrolyte and cardiovascular regulation (6).

Over the past decade there have been numerous studies using intracerebroventricular (icv) administration of ANG II receptor antagonists (4,7-9). Studies with central injection of ANG II antagonists have shown that central angiotensinergic mechanisms are involved in several forms of hypertension. In conscious rats a consistent pressor response is observed after cholinergic activation of several areas of the central nervous system such as the circumventricular structures (1012). Captopril is one of the first potent competitive inhibitors of angiotensin I-converting enzyme (ACE) (13). Recently a new concept has emerged, namely that the inhibition of the local renin-angiotensin system pres- 
ent in many tissues is involved in the antihypertensive action of ACE inhibitors $(14,15)$.

In the present study we determined whether the centrally injected $\mathrm{AT}_{1}$-receptor blocker losartan prevents the pressor response to central carbachol in rats. In order to confirm whether the pressor response to central injection of carbachol implicates the reninangiotensin system we also utilized the converting enzyme inhibitor ramipril to study its effects on the pressor response to carbachol.

Male Holtzman rats weighing 250-300 g were housed in cages with free access to food and water. A stainless steel cannula (0.7 mm O.D.) was stereotaxically implanted into the lateral ventricle (LV). Five days after brain surgery, the rats were submitted to further surgery to cannulate the femoral artery. Arterial pressure was recorded in unanesthetized and unrestrained rats using polyethylene (PE) tubing (PE-10 connected to a PE-50 tube) inserted into the abdominal aorta through the femoral artery. The cannula was tunneled subcutaneously to the back of the rat. On the next day, the line was connected to a Statham $(\mathrm{P} 23 \mathrm{Db})$ pressure transducer (Statham-Gould, Valley View, OH) coupled to a multichannel recorder (Physiograph, Narco Bio-System Inc., Valley View, OH). Carbachol $(2 \mathrm{nmol} / 1 \mu \mathrm{l}$, Sigma Chemical Co., St. Louis, MO), ANG II (12 ng/1 $\mu$, Sigma Chemical Co.), losartan (50 nmol/1 $\mu \mathrm{l}$, DuPont-Merck, Wilmington, DE) and ramipril (12 ng/1 $\mu$, Hoechst, Frankfurt, Germany) were injected into the LV using a

Figure 1 - Increase in mean arterial pressure (MAP) after the injection of ANG II (12 ng/1 $\mu$ l) or carbachol $(2 \mathrm{nmol} / 1 \mu \mathrm{l})$ into the lateral ventricle (LV) and the effect of previous injection of saline or losartan $(50 \mathrm{nmol} / 1 \mu \mathrm{l})$ into the LV. The number of rats is indicated at the top of each column. ${ }^{*} P<0.05$ compared to the response obtained with previous injection of saline (Dunnett $t$ test).

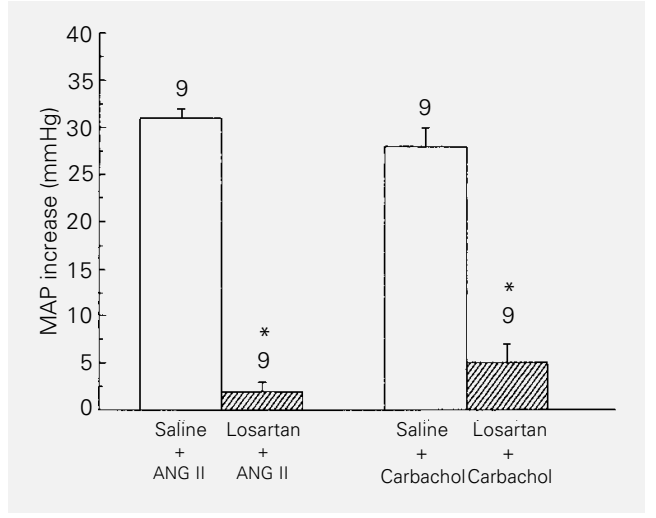

Hamilton $(5 \mu \mathrm{l})$ syringe connected by a PE10 tube to a 34-gauge needle $2 \mathrm{~mm}$ longer than the guide cannula implanted into the animal head. At the end of the experiments, under ether anesthesia, the heart was exposed to intracardiac perfusion with saline followed by $10 \%$ formalin. The brains were removed and stored in $10 \%$ formalin. The tissue was frozen and cut into transverse sections $(20-30 \mu \mathrm{m})$ which were stained with hematoxylin and eosin for analysis by light microscopy to confirm the position of the cannula in the LV. Data are reported as means \pm SEM. Analysis of variance and the Dunnett $t$-test were used to determine statistical significance. Differences were considered to be significant at $\mathrm{P}<0.05$.

Lateral ventricle injection of ANG II (12 $\mathrm{ng} / 1 \mu \mathrm{l})$ and carbachol $(2 \mathrm{nmol} / 1 \mu \mathrm{l})$ produced an immediate and marked increase in mean arterial pressure (MAP) $(31 \pm 1$ and 28 $\pm 2 \mathrm{mmHg}$, respectively). Previous injection of losartan ( $3 \mathrm{~min}$ ) blocked the pressor response induced by ANG II or carbachol $(2 \pm$ $1 \mathrm{mmHg}$ and $5 \pm 2 \mathrm{mmHg}$, respectively, $\mathrm{P}<0.01$ ) (Figure 1). Lateral ventricle injection of ramipril $(12 \mathrm{ng} / 1 \mu \mathrm{l})$ prior to carbachol reduced its pressor effect to $7 \pm 3 \mathrm{mmHg}$ $(\mathrm{P}<0.01)$ (Figure 2).

Our results indicate that the pressor effect of centrally administered carbachol was impaired by previous administration of the $\mathrm{AT}_{1}$-receptor blocker losartan, and ramipril, a converting enzyme inhibitor. A previous study has shown that the sympathetically mediated increase in MAP produced by central administration of beta endorphin (7) is also attenuated by central treatment with an ANG II antagonist.

There are two potential interpretations of these data. The first is that there are central angiotensinergic pathways regulating sympathetic drive which are activated by a variety of potential neurotransmitters, including cholinergic drugs. An alternative hypothesis is that the "global" ability of ANG II antagonists to prevent increases in sympathetic ner- 
vous system activity, particularly in the case of carbachol, may indicate a nonspecific suppression of sympathetic nervous system function. Injection of cholinergic agonists, such as carbachol, into the LV increases water ingestion, vasopressin secretion, MAP and natriuresis. These effects are also produced by central injections of ANG II. The present results indicate that the pressor effect of carbachol involves the central angiotensin system and AT1 receptor activation. The pressor effect of ANG II was previously shown to depend on AT1 receptor activation $(6,15)$ and our data confirm these results $(6,15,16)$. Ramipril is an angiotensin-converting enzyme inhibitor acting as a prodrug, and the present results suggest that this drug may be implicated in the pressor response induced by central cholinergic activation. Our results show that low doses of ramipril were sufficient to alter an endogenous component that blocked the pressor effect induced by LV injection of carbachol. It has been demonstrated that systemic administration of ramipril reduces hypertension (17). The site of carbachol action may be located in the circumventricular structures such as the subfornical organ (SFO) which is a major structure for the action of ANG II in inducing the pressor effect. Ramipril is effective in reducing severe essential hypertension (18). The pressor effect of carbachol injected into the $\mathrm{LV}$ may be due to interaction with the renin-angiotensin system that releases angiotensin. We demonstrated that ramipril blocked the pressor effect of carbachol, possibly due to the inhibition of angiotensin synthesis. In conclusion, our results clearly show the interaction between cholinergic and angiotensinergic pathways in the regulation of blood pressure. This conclusion is based on the fact that the pressor effect of carbachol is blocked by the use of an ACE inhibitor. The participation of angiotensin in this effect was confirmed by the use of an AT1-blocking agent which also blocked the pressor effect of carbachol. It has been dem-

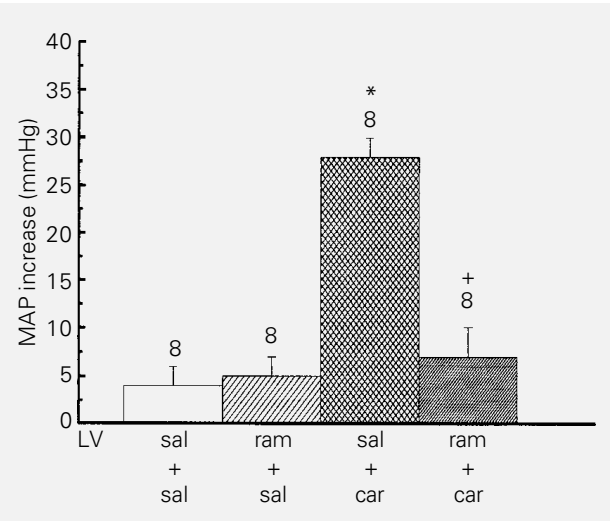

onstrated that chemical sympathectomy with 6-hydroxydopamine (6-OHDA) reduces the water intake induced by ANG II (19). Also, it has been demonstrated that 6-OHDA but not dopamine administration into structures of the ventral lamina terminalis produces ANG II response deficits. These findings are consistent with the interpretation that adrenergic but not dopaminergic neurons must be present in the structures of the ventral lamina terminalis in order to elicit normal angiotensin-induced drinking and pressor responses (20). Taken together, these results lead us to conclude that angiotensin and adrenergic pathways interact to control central pressor effects and that the sympathetic nervous system plays an important role in this control. The cholinergic mechanisms may act with angiotensin or may favor the release of other hormones that produce the pressor effect. As previously demonstrated, the pressor effect of carbachol is not blocked by chemical sympathectomy (19).

\section{Acknowledgments}

We gratefully acknowledge the DuPontMerck Pharmaceutical Company for the donation of losartan (DUP-753). The authors greatly appreciate the technical assistance of Reginaldo C. Queiróz and Silas P. Barbosa. They also thank Silvana A.D. Malavolta for preparation of the manuscript, and Terezinha G.B. Franco and Fernando L. Capelli for animal care.
Figure 2 - Effect of ramipril (ram) injection into the lateral ventricle (LV) on the mean arterial blood pressure (MAP) of rats before LV injection of carbachol (car) or isotonic saline (sal). Results are reported as mean \pm SEM. The number of rats is given at the top of each column. ${ }^{*} \mathrm{P}<0.05$ compared to sal + sal. $+P<0.05$ compared to sal + car (Dunnett t-test). 


\section{References}

1. Hoffman WE \& Phillips MJ (1976). A pressor response to intraventricular injection of carbachol. Brain Research, 105: 157162.

2. Hoffman WE, Phillips MI, Schmid PG, Falcon J \& Weet JF (1977). Antidiuretic hormone release and the pressor response to central angiotensin II and cholinergic stimulation. Neuropharmacology, 16: 463472.

3. Imai $Y$, Abe $K$, Sasaki $S$, Minami N, Munakata M, Yumita S, Nobunaga T, Sekino H \& Yoshinaga K (1989). Role of vasopressin in cardiovascular response to central cholinergic stimulation in rats. $\mathrm{Hy}$ pertension, 13: 549-557.

4. Brody MJ \& Johnson AK (1980). Role of the anteroventral third ventricle region in fluid and electrolyte balance, arterial pressure regulation and hypertension. In: Martini L \& Ganong WF (Editors), Frontiers in Neuroendocrinology. Raven Press, New York, 249-292.

5. Menani JV, Saad WA, Camargo LAA, Renzi A, De Luca Jr LA \& Colombari E (1990). The anteroventral third ventricle (AV3V) region is essential for pressor, dipsogenic and natriuretic responses to central carbachol. Neuroscience Letters, 113: 339-344.

6. Johnson AK \& Loewy AD (1990). Circumventricular organs and their role in visceral functions. In: Loewy AD \& Spyer K (Editors), Central Regulation of Autonomic Functions. Oxford University Press, New York, 247-267.

7. Freer RJ, Sutherland JC \& Day AR (1980). Synthesis and pharmacology of a noncompetitive antagonist of angiotensin-induced contractions of vascular smooth muscle. Circulation Research, 46: 720-725.
8. Tabrizchi R \& Pang CCY (1987). Are angiotensin receptors in vascular smooth muscles a homogenous population? European Journal of Pharmacology, 142: 359-366.

9. Trachte GJ \& Peach MJ (1983). A potent noncompetitive angiotensin II antagonist induces only competitive inhibition of angiotensin II responses. Journal of Cardiovascular Pharmacology, 5: 1025-1033.

10. Colombari DSA, Saad WA, Camargo LAA, Renzi A, De Luca Jr LA, Colombari E \& Menani JV (1992). AV3V lesion impairs responses induced by cholinergic activation of SFO in rats. American Journal of Physiology, 263: R1277-R1283.

11. Colombari E, Saad WA, Camargo LAA, Renzi A, De Luca Jr LA \& Menani JV (1992). AV3V lesion suppresses the pressor, dipsogenic and natriuretic responses to cholinergic activation of the septal area in rats. Brain Research, 572: 172-175.

12. Haibara AS, Saad WA, Camargo LAA, Menani JV, Renzi A, De Luca Jr LA \& Antunes-Rodrigues J (1992). Opiate activation suppresses the drinking, pressor and natriuretic responses induced by cholinergic stimulation of the medial septal area. Brain Research Bulletin, 28: 155160.

13. Robin $B$, Antonaccio MJ \& Horovitz ZP (1978). Captopril (SO 14.225) (D-3mercapto-2-methylpropranoyl-L-proline): a novel orally active inhibitor of angiotensin agent. Progress in Cardiovascular Disease, 21: 183-194.

14. Unger $T$, Ganten $D$, Lang RE \& Scholkens BA (1985). Persistent tissue converting enzyme inhibition following chronic treatment with Hoe 498 and MK 401 in spontaneously hypertensive rats. Journal of Cardiovascular Pharmacology, 7: 36-41.
15. Dzau VJ (1988). Molecular and physiological aspects of tissue renin-angiotensin system: emphasis on cardiovascular control. Journal of Hypertension, 6: S7-S12.

16. Iwai N, Yamano $Y$, Chaki S, Konishi F, Bardhan S, Tibbetts C, Sasaki K, Hasegawa M, Matsuda $Y$ \& Inagami T (1991). Rat angiotensin II receptor: cDNA sequence and regulation of the gene expression. Biochemical and Biophysical Research Communications, 177: 299-304.

17. Karlberg BE, Lindistroem $T$, Rosenquist $V$ \& Oehamn KP (1987). Efficacy, tolerance and hormonal effects of a new oral angiotensin converting enzyme inhibitor, ramipril (HOE-498), in mild to moderate primary hypertension. American Journal of Cardiology, 59: 140D-149D.

18. Predel HG, Duesing R, Baecker A, Kipnowiski J \& Kramer HJ (1987). Combined treatment of severe essential hypertension with the new angiotensin converting enzyme inhibitor ramipril. American Journal of Cardiology, 59: 143D-148D.

19. Cunningham JT \& Johnson AK (1989). Decreased norepinephrine in the ventral lamina terminalis region is associated with angiotensin II drinking response deficits following local 6-hydroxydopamine injections. Brain Research, 480: 65-71.

20. Bellin SI, Landas SK \& Johnson AK (1988) Selective catecholamine depletion of structures along the ventral lamina terminalis: effects on experimentally-induced drinking and pressor responses. Brain Research, 456: 9-16. 